\title{
Effect of biofilmed biofertilizer on plant growth and nutrient uptake of Hevea brasiliensis nursery plants at field condition
}

\author{
R P Hettiarachchi*, G Seneviratne ${ }^{* *}$, A N Jayakody***, E De Silva*, \\ P D T C Gunatilake*, V Edirimanna*, A Thewarapperuma*, \\ J A S Chandrasiri*, G C Malawaraarachchi* and N S Siriwardana* \\ * Rubber Research Institute of Sri Lanka, Dartonfield, Agalawatta, Sri Lanka \\ ** National Institute of Fundamental Studies, Hantana Road, Kandy, Sri Lanka \\ *** Faculty of Agriculture, University of Peradeniya, Peradeniya, Sri Lanka
}

\begin{abstract}
Beneficial microbes through their direct and indirect mechanisms support plant growth in a sustainable manner. This study was conducted to understand the effect of biofilmed biofertilizer $(B F B F)$ on dry matter production and nutrient uptake of Hevea brasiliensis nursery plants. The BFBF was formulated by phosphorus solubilizing bacteria Bacillus spp. and commonly found fungi Aspergillus spp. associated with $\mathrm{H}$. brasiliensis rhizosphere. Rubber Research Institute of Sri Lanka (RRISL) recommended inorganic fertilizers were applied at the rates of $0 \%, 50 \%$ and $100 \%$ of the recommended level with and without the application of BFBF at a rate of $100 \mathrm{ml}$ per rubber nursery plant monthly. Plant dry matter production, nutrient contents of plant parts and their nutrient uptake were determined before and after bud grafting stages. Results showed that many observed growth parameters; diameter, height, shoot dry matter, root dry matter and total dry matter were significantly higher in BFBF applied treatments compared to its respective non BFBF treatments. There was no consistent trend on the effect of BFBF on leaf nutrient contents at both growth stages. There were no significant differences with $100 \% \mathrm{~F}, 50 \% \mathrm{~F}+B F B F$ and $100 \% \mathrm{~F}+B F B F$ treatments in relation to total $N, P$ and $K$ uptake at before bud grafting stage and total $N$ and $K$ uptake at after bud grafting stage. At after bud grafting stage, significantly higher total $P$ uptake was observed in T5 $(50 \% F+B F B F)$ and T6 $(100 \% F+B F B F)$ treatments $(81 \mathrm{mg}$ P/plant and $87 \mathrm{mg} P /$ plant respectively) than in T3 (100\% $)(64 \mathrm{mg}$ $P /$ plant) treatment. This study suggest that reduced amount of inorganic fertilizer with $B F B F$ gave no significant difference or significantly higher values in relation to plant growth and total nutrient uptake of rubber nursery plants compared to recommended fertilizer application.
\end{abstract}

Key words: biofilmed biofertilizer, Hevea brasiliensis, nursery plants, nutrient uptake, plant growth 
R P Hettiarachchi et al.

\section{Introduction}

In general, soils in rubber growing areas of Sri Lanka are deficient in plant nutrients and consequently, considered as less productive (Dissanayake et al., 1999). The same agricultural cropping system adopted with the same management practices throughout the last several decades have resulted in decreasing soil fertility (Samarappuli, 1995 and Samarappuli and Yogaratnam, 1996). Therefore, fertility improvement has been identified as an accepted practice (Samarappuli and Yogaratnam, 1997) and requires a number of nutrients for normal, healthy growth and development of rubber. At present, mineral fertilizers are used to compensate the shortages of nutrients and to manage the soil fertility (Bockman et al., 1990; Thennakoon, 1990). There is a potential loss of nitrogen, phosphorus, potassium and magnesium that could be occur through leaching and runoff while nitrogen could get lost through volatilization and denitrification. Hence, loss of applied fertilizers from the soils leads to marked economic losses and negative environmental impacts (Bockman et al., 1990). Therefore, minimizing leaching of nutrients and volatilization of nitrogen losses associated with chemical fertilizers are required for prevention of unbalanced nutrition promoted through indiscriminative fertilization practices (Ayoub, 1999).

Among the sources available for fertilizing, the use of biofertilizers in agriculture is considered to be an ecofriendly practice which is more cost effective than chemical fertilizers. They are highly advantageous in enrichment of soil fertility and fulfilling the plant nutrient availability. The conventional practice of plant inoculation with monocultures or mixed cultures of effective microbes as biofertilizers may not furnish the highest microbial effect, which may be achieved by biofilm formation (Bandara et al., 2006). Biofilm is a community of microbes and considerable attention has been focused recently on $\mathrm{BFBF}$ and their potential to increase the nutrient availability in soils (Jayasinghearachchi and Seneviratne, 2004a; Seneviratne and Jayasinghearachchi, 2005) and enhance plant growth (Bandara et al., 2006; Seneviratne et al., 2009). The bradyrhizobial-fungal biofilm with nitrogenase activity has showed $\mathrm{N}_{2}$ fixing symbiosis with soybean, but the bradyrhizobial strain alone did not $\mathrm{N}_{2}$ fixing symbiosis (Jasinghearachchi and Seneviratne, 2004b). Moreover, fungalrhizobial biofilms could be used more effectively in biosolubilizing of poorly soluble Eppawala Rock Phosphate (ERP) (Seneviratne and Jasinghearachchi, 2005, Hettiarachchi et al., 2015). The application of BFBF developed from effective microbes have shown to stimulate restoring degraded tropical agricultural lands with improved ecosystem functioning and sustainability (Seneviratne et al., 2011; Seneviratne, 2012). Several studies conducted so far with the BFBF under laboratory, nursery and field conditions for soybean, mung bean, wheat, rice, anthurium and tea in Sri Lanka have shown positive results in relation to soil fertility and crop growth (Seneviratne and Jayasinghearachchi, 
Effect of biofilmed biofertilizer for nursery plants

2005; Seneviratne et al., 2009 and Seneviratne et al., 2011; Seneviratne and Kulasooriya, 2013).

Therefore, this study was conducted with the aim of understanding the effect of BFBF on plant growth and nutrient uptake of Hevea seedling nursery plants.

\section{Materials and Methods}

The top soil belonged to Red Yellow Podzolic (RYP) great soil group and classified as Hapludults according to the USDA soil taxonomy (Mapa et al., 1999) was used without stones, pebbles and roots particles. This top soil was the recommended medium for filling poly bags (Tillekeratne and Nugawela, 2001) with a size of 6" wide, 15" long (lay flat dimension) and contain about $2 \mathrm{~kg}$ of soil. Prior to filling the poly bags the soil was air dried and crushed gently to pass through $2 \mathrm{~mm}$ sieve. Fifty grams of Higher Grade Eppawala Rock Phosphate (HERP) and $50 \mathrm{~g}$ of compost per bag were mixed with soil prior to filling according to the Rubber Research Institute Sri Lanka (RRISL) recommendation for rubber nursery plants. Bags in a single row were arranged close to each other and kept 5 $\mathrm{cm}$ distance between two rows. Two weeks old one germinated seed per bag was placed and Rubber Research Institute recommended management practices were conducted throughout the experimental period (Tillekeratne and Nugawela, 2001). Germinated seeds were grown in poly bags to raise young buddings were bud-grafted by the green budding technique at the age of 3-4 months. Considering that bud-grafting activity two periods were identified as before the bud-grafting and after the budgrafting. Two weeks after planting of seedlings, fertilizer application was started and it was continued throughout the before and after bud-grafting stages until two weeks before planting at field conditions following the recommendation of fertilizer application for rubber nursery plants by RRISL (Tillekeratne and Nugawela, 2001). Recommended $\mathrm{N}, \mathrm{P}, \mathrm{K}$ and $\mathrm{Mg}$ fertilizers were used at $0 \%(0 \% \mathrm{~F}), 50 \%$ $(50 \% \mathrm{~F})$ and $100 \%(100 \% \mathrm{~F})$ of the currently recommended level with and without the application of developed BFBF. There were 6 treatment combinations. The required quantities of $\mathrm{N}, \mathrm{P}, \mathrm{K}$ and $\mathrm{Mg}$ fertilizers were dissolved in water and $100 \mathrm{ml}$ of the solution per bag was applied at monthly intervals. Isolated phosphorus solubilizing bacteria Bacillus spp. and fungi Aspegillus spp. from rubber root rhizosphere had an ability to form complex, multicellular biofilm community called BFBF. It was evaluated under in-vitro conditions and proved its ability of phosphorus solubilizing, $\mathrm{N}_{2}$ fixing and secreting plant growth promoting hormones. The BFBF medium was examined under the microscope using a hemocytometer and cell density was adjusted to $10^{8}-10^{9}$ cells $\mathrm{ml}^{-1}$. The freshly prepared BFBF was applied as a liquid at equal rate for inorganic fertilizers. Each treatment had 5 replicates and each replicate consisted of 10 poly baged plants. Each replicate was maintained in different steps of the land and there was a variation in sunlight at the site. Hence, treatments were arranged in a randomized complete block design. 
R P Hettiarachchi et al.

When the seedling plants reached their grafting stage, $6 \mathrm{~mm}$ in diameter above the soil level (Tillekeratne and Nugawela, 2001) was grafted with the clone RRISL 203. One month after, successfully grafted seedling plants were pollarded and facilitated for sprouting the desired bud patch. Therefore, both stages (before and after bud grafting) important for the final outcome of the preparation of quality planting material for rubber plantation. End of four months of before and after bud grafting stages, randomly selected five plants from each treatment were collected for data collection.

\section{Growth assessments}

Plant height was measured as the total height above the soil level and diameter was measured at $1 \mathrm{~cm}$ above the base of the plant and bud union at before bud grafting stage and after bud grafting stage respectively throughout the experimental period at one month interval.

\section{Plant dry matter}

At the end of four months at before and after bud grafting stages each plant was separated into leaves, stems, roots and their dry weights only were recorded by drying the components at $60^{\circ} \mathrm{C}$ for constant weight. At the time of separating plants into their parts special care was taken to collect almost entire root system. Soil and dust particles adhered to the root system were removed carefully.

\section{Plant analysis}

Dried samples were ground in a Willy mill. $0.2 \mathrm{~g}$ of finely ground plant materials were weighed into a pyrex tube and $5 \mathrm{ml} \mathrm{Se} / \mathrm{H}_{2} \mathrm{SO}_{4}$ mixture and $1 \mathrm{ml}$ of ' 100 vol' $\mathrm{H}_{2} \mathrm{O}_{2}$ were added to each. The tubes were then heated to $350-400^{\circ} \mathrm{C}$ for around two hours in a digestion unit. When the heated samples became colorless, the solution was kept to cool for another 2 hours. Ten $\mathrm{ml}$ of distilled water were added to the digest and the digest was thoroughly washed with distilled water and transferred to $50 \mathrm{ml}$ volumetric flasks and made up to volume. This solution was used for the determination of nutrient contents (RRIM 1971b).

Nitrogen (N) and phosphorus (P) contents were determined using a SKALAR San ${ }^{++}$Auto analyzer and potassium (K) using a GBC 203 Atomic Absorption Spectrophotometer. Nutrient uptake was calculated as the nutrient content of plant part; leaf, stem and root multiply by their total dry weight of each plant part.

\section{Statistical analysis}

Statistical analysis of the experimental data viz; plant height, plant diameter, total plant dry matter, nutrient contents; $\mathrm{N}, \mathrm{P}$ and $\mathrm{K}$ of leaf, stem and root, N, P and $\mathrm{K}$ nutrient uptake of shoot, root and total plant were done by Analysis of variance (ANOVA) is for the RCBD. Subsequently, mean separation was done employing Duncan's Multiple Range Test (DMRT). 


\section{Results}

Growth parameters were measured at before and after bud grafting stages are given in Table 1 and 2 respectively.

Plant growth parameters; diameter, height and shoot dry weight gave significantly higher values with $100 \% \mathrm{~F}$ (T3), 50\%F+BFBF (T5) and $100 \% \mathrm{~F}+\mathrm{BFBF} \quad$ (T6) treatments compared to other treatments; $0 \% \mathrm{~F}$ (T1), $50 \% \mathrm{~F}(\mathrm{~T} 2)$ and BFBF (T4) treatments at before bud grafting stage. Same pattern could be observed with diameter, shoot dry weight, root dry weight and total dry weight at after bud grafting stage. There is no significant difference in many growth parameters with $100 \% \mathrm{~F}$ (T3), $50 \% \mathrm{~F}+\mathrm{BFBF}(\mathrm{T} 5)$ and $100 \% \mathrm{~F}+\mathrm{BFBF}$ (T6) treatments. Other growth parameters were higher in BFBF included treatments; $50 \% \mathrm{~F}+\mathrm{BFBF}$ (T5) and $100 \% \mathrm{~F}+\mathrm{BFBF}$ (T6) compared to $100 \% \mathrm{~F}$ (T3) treatment.

Table 1. Plant growth parameters were measured at before bud grafting stage of nursery plants as affected by different combinations of fertilizer applications

\begin{tabular}{llllll}
\hline Treatment & $\begin{array}{l}\text { Diameter } \\
(\mathbf{m m})\end{array}$ & $\begin{array}{l}\text { Height } \\
(\mathbf{c m})\end{array}$ & $\begin{array}{l}\text { Shoot dry } \\
\text { matter } \\
(\mathbf{g} / \text { plant })\end{array}$ & $\begin{array}{l}\text { Root dry } \\
\text { matter } \\
(\mathbf{g} / \text { plant })\end{array}$ & $\begin{array}{l}\text { Total dry } \\
\text { matter } \\
(\text { g/plant })\end{array}$ \\
\hline $0 \% \mathrm{~F}$ & $6.7^{\mathrm{c}}$ & $69.4^{\mathrm{c}}$ & $12.7^{\mathrm{c}}$ & $6.6^{\mathrm{c}}$ & $19.3^{\mathrm{c}}$ \\
$50 \% \mathrm{~F}$ & $7.8^{\mathrm{b}}$ & $68.4^{\mathrm{c}}$ & $21.4^{\mathrm{b}}$ & $8.6^{\mathrm{b}}$ & $30^{\mathrm{b}}$ \\
$100 \% \mathrm{~F}$ & $8.5^{\mathrm{a}}$ & $78.0^{\mathrm{ab}}$ & $25.3^{\mathrm{a}}$ & $9.6^{\mathrm{b}}$ & $34.9^{\mathrm{ab}}$ \\
$\mathrm{BFBF}$ & $7.3^{\mathrm{bc}}$ & $69.75^{\mathrm{c}}$ & $19.3^{\mathrm{b}}$ & $8.7^{\mathrm{b}}$ & $28^{\mathrm{b}}$ \\
$50 \% \mathrm{~F}+\mathrm{BFBF}$ & $9.05^{\mathrm{a}}$ & $82.16^{\mathrm{a}}$ & $25.9^{\mathrm{a}}$ & $11.1^{\mathrm{a}}$ & $37^{\mathrm{a}}$ \\
$100 \% \mathrm{~F}+\mathrm{BFBF}$ & $8.7^{\mathrm{a}}$ & $85.08^{\mathrm{a}}$ & $28.6^{\mathrm{a}}$ & $12.6^{\mathrm{a}}$ & $41.2^{\mathrm{a}}$ \\
\hline
\end{tabular}

(Means with same letters along the column are not significantly different at 5\% probability level)

Table 2. Plant growth parameters were measured at after bud grafting stage of nursery plants as affected by different combinations of fertilizer applications

\begin{tabular}{llllll}
\hline Treatment & $\begin{array}{l}\text { Diameter } \\
(\mathbf{m m})\end{array}$ & $\begin{array}{l}\text { Height } \\
(\mathbf{c m})\end{array}$ & $\begin{array}{l}\text { Shoot dry } \\
\text { matter } \\
(\mathbf{g} / \mathbf{p l a n t})\end{array}$ & $\begin{array}{l}\text { Root dry } \\
\text { matter } \\
(\mathbf{g} / \mathbf{p l a n t})\end{array}$ & $\begin{array}{l}\text { Total dry } \\
\text { matter } \\
(\mathbf{g} / \mathbf{p l a n t})\end{array}$ \\
\hline $0 \% \mathrm{~F}$ & $6.3^{\mathrm{c}}$ & $69.7^{\mathrm{c}}$ & $15.9^{\mathrm{c}}$ & $7.0^{\mathrm{c}}$ & $22.9^{\mathrm{d}}$ \\
$50 \% \mathrm{~F}$ & $7.0^{\mathrm{b}}$ & $71.1^{\mathrm{c}}$ & $18.4^{\mathrm{b}}$ & $8.7^{\mathrm{b}}$ & $27.1^{\mathrm{c}}$ \\
$100 \% \mathrm{~F}$ & $8.1^{\mathrm{a}}$ & $78.6^{\mathrm{b}}$ & $22.6^{\mathrm{a}}$ & $9.9^{\mathrm{a}}$ & $32.5^{\mathrm{b}}$ \\
$\mathrm{BFBF}$ & $7.5^{\mathrm{b}}$ & $68.7^{\mathrm{c}}$ & $17.75^{\mathrm{bc}}$ & $7.6^{\mathrm{c}}$ & $25.3^{\mathrm{c}}$ \\
$50 \% \mathrm{~F}+\mathrm{BFBF}$ & $8.5^{\mathrm{a}}$ & $78.9^{\mathrm{b}}$ & $29.3^{\mathrm{a}}$ & $10.3^{\mathrm{a}}$ & $39.6^{\mathrm{a}}$ \\
$100 \% \mathrm{~F}+\mathrm{BFBF}$ & $8.6^{\mathrm{a}}$ & $85.7^{\mathrm{a}}$ & $29.6^{\mathrm{a}}$ & $10.2^{\mathrm{a}}$ & $39.7^{\mathrm{a}}$ \\
\hline
\end{tabular}

(Means with same letters along the column are not significantly different at 5\% probability level) 
R P Hettiarachchi et al.

Nutrient concentrations were measured in the leaves collected at before and after bud grafting stages are given in Table 3 . In both stages $\mathrm{P}$ concentrations of the leaf samples were not significantly affected by the treatments. $0 \%$ fertilizer (T1) treatment and BFBF treatment (T4) gave significantly lower values of leaf $\mathrm{N}$ concentrations compared to other treatments; $50 \% \mathrm{~F}(\mathrm{~T} 2), 100 \% \mathrm{~F}(\mathrm{~T} 3)$, $50 \% \mathrm{~F}+\mathrm{BFBF}(\mathrm{T} 5)$ and $100 \% \mathrm{~F}+\mathrm{BFBF}$ (T6) at both growth stages. At before bud grafting stage $100 \% \mathrm{~F}$ (T3) treatment increased leaf $\mathrm{K}$ level significantly compared to other treatments. Furthermore, significantly lower value of leaf $\mathrm{K}$ contents could be observed with $0 \% \mathrm{~F}$ (T1) treatment compared to other treatments.

At after bud grafting stage, BFBF applied treatments; BFBF (T4) and $50 \% \mathrm{~F}+\mathrm{BFBF}$ (T5) gave significantly higher values of leaf $\mathrm{K}$ contents compared to their respective non $\mathrm{BFBF}$ treatments; $0 \% \mathrm{~F}(\mathrm{~T} 1)$ and $50 \% \mathrm{~F}(\mathrm{~T} 2)$.

Table 3. Effect of different combinations of fertilizer applications on leaf nutrient contents of nursery plants at before and after bud grafting stages

\begin{tabular}{llllllll}
\hline \multirow{2}{*}{ Treatment } & \multicolumn{2}{l}{$\begin{array}{l}\text { Leaf nutrient contents } \\
\text { before bud grafting stage }\end{array}$} & \multicolumn{4}{c}{ at } & \multicolumn{2}{l}{$\begin{array}{l}\text { Leaf nutrient contents } \\
\text { after bud grafting stage }\end{array}$} \\
\cline { 2 - 8 } & $\mathbf{N}$ & $\mathbf{P}$ & $\mathbf{K}$ & $\mathbf{N}$ & $\mathbf{P}$ & $\mathbf{K}$ \\
\hline $0 \% \mathrm{~F}$ & $1.83^{\mathrm{c}}$ & $0.23^{\mathrm{a}}$ & $0.597^{\mathrm{c}}$ & $1.77^{\mathrm{c}}$ & $0.23^{\mathrm{a}}$ & $0.63^{\mathrm{b}}$ \\
$50 \% \mathrm{~F}$ & $2.27^{\mathrm{ab}}$ & $0.215^{\mathrm{a}}$ & $0.720^{\mathrm{b}}$ & $2.42^{\mathrm{ab}}$ & $0.22^{\mathrm{a}}$ & $0.69^{\mathrm{b}}$ \\
$100 \% \mathrm{~F}$ & $2.59^{\mathrm{a}}$ & $0.233^{\mathrm{a}}$ & $0.807^{\mathrm{a}}$ & $2.64^{\mathrm{a}}$ & $0.24^{\mathrm{a}}$ & $0.8^{\mathrm{a}}$ \\
$\mathrm{BFBF}$ & $1.78^{\mathrm{c}}$ & $0.245^{\mathrm{a}}$ & $0.740^{\mathrm{b}}$ & $1.76^{\mathrm{c}}$ & $0.25^{\mathrm{a}}$ & $0.8^{\mathrm{a}}$ \\
$50 \% \mathrm{~F}+\mathrm{BFBF}$ & $2.05^{\mathrm{b}}$ & $0.233^{\mathrm{a}}$ & $0.700^{\mathrm{b}}$ & $2.08^{\mathrm{b}}$ & $0.25^{\mathrm{a}}$ & $0.76^{\mathrm{a}}$ \\
$100 \% \mathrm{~F}+\mathrm{BFBF}$ & $2.2^{\mathrm{ab}}$ & $0.24^{\mathrm{a}}$ & $0.765^{\mathrm{b}}$ & $2.56^{\mathrm{ab}}$ & $0.26^{\mathrm{a}}$ & $0.76^{\mathrm{a}}$ \\
\hline
\end{tabular}

(Means with same letters along the column are not significantly different at 5\% probability level)

Table 4. Effect of different combinations of fertilizer applications on total nutrient uptake of nursery plants at before and after bud grafting stages

\begin{tabular}{lllllll}
\hline \multirow{2}{*}{ Treatment } & \multicolumn{3}{c}{$\begin{array}{c}\text { Total nutrient uptake (mg/plant) } \\
\text { at before bud grafting stage }\end{array}$} & \multicolumn{3}{c}{$\begin{array}{r}\text { Total nutrient uptake (mg/plant) } \\
\text { at after bud grafting stage }\end{array}$} \\
\cline { 2 - 7 } & $\mathbf{N}$ & $\mathbf{P}$ & $\mathbf{K}$ & $\mathbf{N}$ & $\mathbf{P}$ & $\mathbf{K}$ \\
\hline $0 \% \mathrm{~F}$ & $116^{\mathrm{c}}$ & $19^{\mathrm{c}}$ & $123^{\mathrm{c}}$ & $205^{\mathrm{c}}$ & $38^{\mathrm{c}}$ & $176^{\mathrm{c}}$ \\
$50 \% \mathrm{~F}$ & $319^{\mathrm{b}}$ & $41^{\mathrm{ab}}$ & $262^{\mathrm{b}}$ & $283^{\mathrm{b}}$ & $50^{\mathrm{c}}$ & $270^{\mathrm{b}}$ \\
$100 \% \mathrm{~F}$ & $377^{\mathrm{a}}$ & $46^{\mathrm{ab}}$ & $334^{\mathrm{ab}}$ & $421^{\mathrm{a}}$ & $64^{\mathrm{b}}$ & $342^{\mathrm{ab}}$ \\
$\mathrm{BFBF}$ & $159^{\mathrm{c}}$ & $37^{\mathrm{b}}$ & $193^{\mathrm{c}}$ & $173^{\mathrm{c}}$ & $48^{\mathrm{c}}$ & $209^{\mathrm{c}}$ \\
$50 \% \mathrm{~F}+\mathrm{BFBF}$ & $340^{\mathrm{ab}}$ & $53^{\mathrm{a}}$ & $410^{\mathrm{a}}$ & $403^{\mathrm{a}}$ & $81^{\mathrm{a}}$ & $407^{\mathrm{a}}$ \\
$100 \% \mathrm{~F}+\mathrm{BFBF}$ & $347^{\mathrm{ab}}$ & $52^{\mathrm{a}}$ & $390^{\mathrm{a}}$ & $450^{\mathrm{a}}$ & $87^{\mathrm{a}}$ & $398^{\mathrm{a}}$ \\
\hline
\end{tabular}

(Means with same letters along the column are not significantly different at 5\% probability level) 
Total nutrient uptakes of the plant at both growth stages were calculated by using the data of nutrient concentrations in different plant parts and their dry weights are given in Table 4.

Calculation of nutrient uptake

Nitrogen uptake of shoot

$=$ leaf dry wt. $\mathrm{x}$ leaf nitrogen content + shoot dry wt. $\mathrm{x}$ shoot nitrogen content

Phosphorus uptake of shoot = leaf dry wt. $\mathrm{x}$ leaf phosphorus content + shoot dry wt. $\mathrm{x}$ shoot phosphorus content

In both stages, total $\mathrm{N}$ uptake gave significantly higher value with $50 \% \mathrm{~F}$ (T2), $100 \% \mathrm{~F}$ (T3), 50\%F+BFBF (T5) and $100 \% \mathrm{~F}+\mathrm{BFBF}$ (T6) treatments compared to $0 \% \mathrm{~F}$ (T1) and BFBF (T4) treatments. Same pattern could be observed with total $\mathrm{K}$ uptake at both growth stages. Moreover, there were no significant differences with $100 \% \mathrm{~F}$ (T3), $50 \% \mathrm{~F}+\mathrm{BFBF}$ (T5) and $100 \% \mathrm{~F}+\mathrm{BFBF}$ (T6) treatments in relation to total $\mathrm{N}$ and $\mathrm{K}$ uptake at both stages. At after bud grafting stage significantly higher total $\mathrm{P}$ uptake with $50 \% \mathrm{~F}+\mathrm{BFBF}$ (T5) and $100 \% \mathrm{~F}+\mathrm{BFBF}$ (T6) treatments $(81 \mathrm{mg}$ $\mathrm{P} /$ plant) and $87 \mathrm{mg} \mathrm{P} /$ plant) than those in $100 \% \mathrm{~F}$ (T3) (64 mg P/plant) treatment.

\section{Discussion}

Fertilizer application according to RRISL recommendations is an accepted practice for rubber in their different stages of rubber nursery, immature rubber and mature rubber to achieve their maximum growth and yield. This was further confirmed by an observation of significantly higher growth parameters of nursery plants with recommended fertilizer application treatment (T3) compared to no fertilizer application treatment (T1) in both growth stages on this study.
Due to low value of cation exchange capacity (CEC) in rubber growing soils added fertilizers can be frequently lost through leaching as well. Phosphorus availability is very low in rubber growing soils and found that $\mathrm{P}$ fixation is very high in respect to their high availability of $\mathrm{Fe}$ and $\mathrm{Al}$ contents in the soil (Dharmakeerthi et al., 2010; Silva et al., 1977).

Biofilm showed high nitrogenase activity (Jayasinhearachchci and Seneviratne, 2004b; Seneviratne and Jayasinghearachchi, 2005) and biosolubilization of rock phosphate enhanced availability of nitrogen and phosphorus in the soil (Jayasinghearachchi and Seneviratne, 2006a; Seneviratne and Indrasena, 2006). Bandara et al. (2006) observed that the conventional practice of plant inoculation with monocultures or mixed cultures of microbes may not facilitate the highest microbial effect in biological $\mathrm{N}_{2}$ fixation, mineral nutrient release organic acids and plant growth hormone production etc. and may only be better achieved by biofilm formation. Hettiarachchi et al., 2012 observed that BFBF treated soils showed significantly higher microbial biomass content (MBC) which reflected the buildup of soil 
R P Hettiarachchi et al.

microbial communities.
microorganisms are of importance in nutrient cycling processes and also source and sink of plant nutrients.

Results showed that $60 \%$ of the observed plant growth parameters were significantly higher in BFBF treatments compared to its respective non BFBF treatments at both growth stages. No significant differences between $100 \% \mathrm{~F}$ (T3) treatment and 50\% F+BFBF (T5) treatment for more growth parameters and rest of them were significantly higher with $50 \% \mathrm{~F}+\mathrm{BFBF}$ treatment compared to $100 \% \mathrm{~F}$ treatment (Table $1 \& 2)$.

Several studies conducted so far with biofertilizers and BFBF have shown positive results. Hettiarachchi et al., 2012 observed that the combined use of $50 \%$ recommended fertilizer with BFBF recorded the highest values for most growth parameters in rubber nursery plants under greenhouse conditions. Seneviratne et al., (2008a) observed that biofilm attached to the plant root of some crops help in cycling of nutrients and biocontrol of pests and diseases, resulting in enhancing of plant growth accompanied with improved agricultural productivity. Improved growth parameters with reduced rates of chemical fertilizer and BFBF were also recorded with tea plantations in Sri Lanka (Seneviratne et al., 2009 and 2011) and China (Hvistentendahl, 2010). Khan, 2018 observed the performances of rice plant were better when $25 \%$ less inorganic $\mathrm{N}$ was applied with Trichoderma and combined application of Trichoderma and Azospirillum.
Nafady et al., 2018 observed that the total dry mass of Vicia faba was increased significantly by the application of arbuscular mycorrhizal fungi and biofertilizer compared with noninoculated plants. Mahanta et al., 2014 observed that the inoculation of phosphorus solubilizing bacteria (BSB) and vesicular arbusculatar (VAM) could substitute $50 \% \mathrm{P}$ of soybean - wheat cropping system with better root property and higher grain yield.

According to the enhancement of growth parameters, improvement of leaf nutrient status could not be observed under present study. Further leaf nutrient contents and total nutrient uptake showed that $25 \%$ of the observed nutrient levels were significantly higher in BFBF treatments compared to its respective non BFBF treatments (Table 3 $\& 4)$. Rest of the observation gave no significant differences between BFBF treatments compared to its respective non BFBF treatments except one occasion. Out of 12 combinations of $100 \% \mathrm{~F}(\mathrm{~T} 3)$ and $50 \% \mathrm{~F}+\mathrm{BFBF}(\mathrm{T} 5)$ for different leaf nutrients and their total nutrient uptake showed no significant differences except three occasions. Dawwam et al., 2013 reported that inoculated potato plants showed significant differences in vegetative growth parameters as well as photosynthetic pigments and $\mathrm{N}, \mathrm{P}$ and $\mathrm{K}$ concentrations compared with control. Similar to that Silva et al., 2016 observed high rate application of bio protector and biofertilizer gave increased chemical characteristics and nutrient uptake of melon plant compared to soluble 
fertilizer applied in the recommended rate.

Moreover, some other studies have reported similar to above mentioned observations of their studies by the application of microbial inoculants as biofertilizers (Mukhtar et al., 2017; Dutta et al., 2017; Andrade et al., 2013; Gupta et al., 2012; Tejada et al., 2016). Biofertilizer or BFBF is a term used for the products including living or dormant micro-organisms (Rai, 2006). They are an alternative to mineral fertilizers for increasing soil productivity and plant growth in sustainable agriculture. Recently, there is an increasing interest in this type of environmental friendly, sustainable agricultural practices to alleviate deterioration of nature and environmental pollution (Gauda et al., 2018). They may support the plant growth by several mechanisms such as decomposing organic materials and release inorganic nutrients, increasing the availability of nutrients in the soil by solubilization, chelation, oxidation and reduction processes, increasing root surface area by inducing root growth promotion, enhancing other beneficial symbiosis associated with plant and by combination of mode of actions etc. (Vessely, 2003; Anderson et al., 1993; Whiting et al., 2001; Jing et al., 2007).

\section{Conclusion}

RRISL recommended fertile top soil is not available in most of the rubber nurseries in Sri Lanka. Soil Analysis of the poly bag filling indicated mean values for the: $\mathrm{pH} 4.6$; CEC 2.3 (c mol (+) $\mathrm{kg}^{-1}$; total nitrogen $0.097 \%$; available phosphorus 10 - 12 ppm; potassium 112 ppm and magnesium 223 ppm. Due to low values of CEC in the soils added fertilizers can be frequently lost through leaching as well. Therefore, fertility management is an important aspect for the production of quality planting material of rubber.

This study showed that the enhancement of many growth parameters (around $60 \%$ ) could be observed with BFBF treatments compared to its respective non BFBF treatments. Further, $50 \% \mathrm{~F}+$ BFBF (T5) and $100 \% \mathrm{~F}$ (T3) gave comparable growth parameters for more assessments and rest of them were significantly higher with $50 \% \mathrm{~F}+\mathrm{BFBF}$ (T5) treatment compared to $100 \% \mathrm{~F}$ (T3) treatment. Moreover, their total nutrient uptake showed no significant differences frequently.

It can therefore be concluded that there is a possibility of using BFBF to improve growth and nutrient uptake of rubber seedling plants with modified levels of chemical fertilizers under field condition.

\section{Acknowledgement}

Statistical analysis was conducted by $\mathrm{Dr}$ Wasana Wijesuriya, Principal Research Officer of Biometry Section is gratefully acknowledged.

\section{References}

Anderson, T A and Walton, B T (1993). Bioremediation in rhizosphere: plant roots and associated microbes clean contaminated soil. Environment Science Technology 27, 2630-2636.

Andrade, M M M, Stamford, N P, Santos, C E R S, Freitas, A D S, Sousa, C A and Junior, M A L (2013). Effects of 
R P Hettiarachchi et al.

biofertilizer with diazotrophic bacteria and mycorrhizal fungi in soil attribute, cowpea modulation yield and nutrient uptake in field conditions. Scientia Horticulturae 162, 374-379.

Anon (2009). Fertilizer to Rubber. Advisory Circular No.2009. Rubber Research Institute of Sri Lanka.

Ayoub, A T (1999). Fertilizer and the environment. Nutrient Cycling in Agroecosystem 55, 117-121.

Bandara, W M M S, Seneviratne, G and Kulasooriya, S A (2006). Interactions among endophytic bacteria and fungi: effects and potentials. Journal of Bioscience 31, 645-650.

Bockman, O C, Kaarstad, O, Lie, O H and Richards, I (1990). Agriculture and fertilizers: Fertilizers in perspective. Oslo: Norsk hydro. Borlaug, N E and C R Dowswell, 1994.

Dawwam, G E, Emara, H M, Abbas, I H, Elbeltagy, A and Hassan, M M (2013). Beneficial effect of plant growth promoting bacteria isolated from the roots of potato plants. Annals of Agricultural Science 58(2), 195-201.

Dharmakeerthi, R S, Chandrasiri, J A S and Edirimanne, V U (2010). Use of biochar as a soil amendment in rubber (Hevea brasiliensis) plantations: Effectiveness in young budding polybagged plants. Proceedings of the $3^{\text {rd }}$ Symposium on Plantation Crop Research. (Eds. R S Dharmakeerthi and A M W K Senevirathna), Rubber Research Institute of Sri Lanka, Agalawatta, Sri Lanka. 179188.

Dissanayake, S T B, Wijewardena, J D H and Samarappuli, L (1999). Management of the Wet Zone soils. In: Soils of Wet Zone of Sri Lanka, pp. 160-175 (Eds. R B Mapa, S Somasiri and S Nagarajah), Soil Science Society of Sri Lanka.

Dutta, S, Datta, J K and Mandal, N C (2017). Evaluation of indigenous rhizobacterial strains with reduced dose of chemical fertilizer towards growth and yield of mustard (Brassica campestris) under old alluvial zone soil of West Bengal, India. Annals of Agrarian Science 15(4), 447452.

Gouda, S, Kerry, R G, Das, G, Patra, J K, Paramithiotis, S and Shin, H (2018). Revitalization of plant growth promoting rhizobacteria for sustainable development in agriculture. Microbiological Research 206, 131-140.

Gupta, M, Tewari, R, Kiran, S, Gulati, A and Singh, B (2012). Isolation and identification of phosphate solubilizing bacteria able to enhance the growth and aloin-A biosynthesis of Aloe barbadensis Miller. Microbiological Research 167(6), 358-363

Hettiarachchi, R P, Dharmakeerthi, R S, Seneviratne, G, Jayakody, A N and Edirimanna, V (2012). Effect of biofilm bio fertilizers on growth and mineral composition of Hevea seedlings under greenhouse conditions. (Eds. L S K Hettiarachchi and I S B Abeysinghe) Proceedings of the $4^{\text {th }}$ Symposium on Plantation Crop Research Technological Innovations for Sustainable Plantation Economy. 195204. Tea Research Institute of Sri Lanka, St. Coombs, Talawakelle, Sri Lanka.

Hettiarachcchi, R P, Dharmakeerthi, R S, Seneviratne, G, Jayakody, A N, De Silva E, Gunathilaka, T and Thewarapperuma, A (2015). Determination of desirable properties of bacteria, fungi and biofilm associated with rubber rhizosphere. Tropical Agriculture Research 26(4), 399-413.

Hvistentendahl, M (2010). Fertilizer is acidifying Chinese land. Journal of Science News.

Jayasinghearachchi, H S and Seneviratne, G (2004a). Can mushrooms fix 
Effect of biofilmed biofertilizer for nursery plants

atmospheric nitrogen. Journal of Bioscience 23, 293-296.

Jayasinghearachchi, H S and Seneviratne, G (2004b). A bradyrhizobial-penicillium spp biofilm with nitrogenase activity improves $\mathrm{N} 2$ fixing symbiosis of soybean. Biology and Fertility of Soils 40, 432-434.

Jayasinghearachchi, H S and Seneviratne, G (2006). A mushroom-fungus helps improve endophytic colonization of tomato by Pseudomonas fluorescenc through biofilm formation. Research Journal of Microbiology 1(1), 83-89.

Jing, E, Gester, S and Khan, C R (2007). SIRT2 regulates epdipocyte differentiation through FoxO1 acetylation/deacetylation. Cell Metab 6(2), 105.

Khan, H I (2018). Appraisal of biofertilizers in rice: To supplement inorganic chemical fertilizer. Science Direct 25(6), 357-362.

Mahanta, D, Rai, R K, DharMishra, S, Raja, Arunkumar, Purakayastha, T J and Varghese, E (2014). Influence of phosphorus and biofertilizers on soybean and wheat root growth and properties. Field Crops Research 166, 1-9.

Mapa, R B, Somasiri, S and Nagarajah, S (1999). Soils of wet zone of Sri Lanka. Soil Science Society of Sri Lanka.

Mukhtar, S, Shahid, Z, Mehnaz, S and Malik, K A (2017). Assessment of two carrier materials for phosphate solubilizing biofertilizers and their effect on growth of wheat (Triticum aestivum L.). Microbiological Research 205, 107-117.

Nafady, N A, Ahmed, A, Mohamed, H, AbdAlla, H, Mohamed, $\mathrm{M}$ and Bagy, K (2018). Effectiveness of eco-friendly arbuscular mycorrhizal fungi biofertilizer and bacterial feather hydrolysate in promoting growth of Vicia faba in sandy soil. Biocatalysis and Agricultural Biotechnology 16, 140-147.
Rai, M K (2006). Handbook of Microbial Biofertilizers. Haworth Press, New York.

Rubber Research Institute of Malaysia (1971b). Manual of Laboratory Methods of Soil Analysis.

Samarappuli, L and Yogaratnam N (1996). Soil degradation and development practices in Hevea plantations. Journal of the National Institute of Plantation Management 12(1), 48-60.

Samarappuli, L and Yogaratnam, N (1997). Soil Management Practices in Rubber Plantation and their Effect on the Environment. 35, 7-18.

Samarappuli, L (1995). The contribution of rubber plantations towards a better environment. Journal of the Rubber Research Institute Sri Lanka 2, 91-107.

Seneviratne, G and Indrasena, I K (2006). Nitrogen fixation in lichens is important for improved rock weathering. Journal of Biosciences 31, 639-643.

Seneviratne, G and Jayasinghearachchi, H S (2005). A rhizobial biofilm with nitrogenase activity alters nutrient availability in soil. Soil Biology \& Biochemistry 37, 1975-1978.

Seneviratne, G and Kulasooriya, S A (2013). Reinstating soil microbial diversity in agroecosystem: the need of the hour for sustainability and health. Agriculture, Ecosystems \& Environment 164, 181182.

Seneviratne G, Zavahir, J S, Bandara, W M M S and Weerasekara, M L M A W (2008a). Fungal-bacterial biofilms their development for novel biotechnological applications. World Journal of Microbiology \& Biotechnology 24, 739743.

Seneviratne, G, Keeskes, M L and Kennedy, I R (2008b). Biofilm biofertilizers: novel inoculants for efficient use in plants. In: Efficient nutrient use in rice production in Vietnam achieved using inoculants biofertilizers. Proceeding of a project 
R P Hettiarachchi et al.

(SMCN/2002/073), (Eds. I.R. Kenedy et al.) Workshop held in Hanoi, Vietnam. 126-130.

Seneviratne, G, Thilakaratne, R M M S, Jayasekara, A P D P, Seneviratne, K A C N, Padmathilake, K R E and De Silva, M S D L (2009). Developing beneficial microbials on root of non legumes: A novel biofertilizing technique. In: Microbial Strategies for Crop Improvement (Eds. M S Khan et al.), Springer-Verlag. Berlin Heidelberg. 5162.

Seneviratne, G, Jayasekara A P D A, De Silva, M S D L and Abeysekara, U P (2011). Developed microbial biofilms can restore deteriorated conventional agricultural soils. Journal Soil Biology and biochemistry 43, 1059-1062.

Seneviratne, G (2012). Are we wrong in conventional approach in biocontrol. 1395-1396.

Silva, C G, Kulasuriya, $\mathrm{K}$ and Wickramasinghe, L J (1977). The efficient use of phosphatic fertilizer in relation to the phosphorus fixing capacity of rubber soils. Journal of the Rubber Research Institute of Sri Lanka 54, 263269.

Silva, W O, Stamford, N P, Silva, E V N, Santos, C E R S, Freitas, A D S and Silva, M V (2016). The impact of biofertilizers with diazotrophic bacteria and fungi chitosan on melon characteristics and nutrient uptake as an alternative for conventional fertilizers. Scientia Horticulturea 209, 236-240.

Tejada, M, Gomez, I, Andreu, L F, Morgado, B R and Benitez, C (2016). Use of biofertilizers obtained from sewage sludges on maize yield. European Journal of Agronomy 78, 13-19.

Thennakoon, N A (1990). Goat manure as a soil 'ameliorant' and yield 'stimulant' in coconut. Cocos. Coconut Research Institute of Sri Lanka 8, 26-32.

Tillekaratne, L M K and Nugawela, A (2001). Handbook of Rubber. Vol.1. Agronomy, Rubber Research Institute of Sri Lanka, Agalawatta, Sri Lanka.

Vessey, J K (2003). Plant growth promoting rhizobacteria as biofertilizers. Plant Soil 255, 571-586.

Whiting, S N, De Souza, S P and Terry, N (2001). Rhizosphere bacteria mobilize $\mathrm{Zn}$ for hyperaccumulation by Thlaspi caerulescens. Environment, Science and Technology 35, 3144-3150.

Address for correspondence: Dr (Mrs) R P Hettiarachchi, Principal Research Officer, Soils \& Plant Nutrition Dept., Rubber Research Institute of Sri Lanka, Dartonfield, Agalawatta, Sri Lanka. e-mail: rasikarri@yahoo.com 